\title{
Skibe på ruller og i kanaler \\ Myter, spekulation og forskning omkring \\ et Danevirke-problem \\ Af Helmuth Schledermann
}

En tidlig junidag i 1963 kørte jeg med en $x$ ldre geolog gennem marsken ved Ribe. Man vidste dengang ikke, hvor Ansgars Ribe havde ligget, og vi skulle efterprøve en teori herom. Glitrende sollys og lrerkekvidren - men vi talte om stormfloder. Han berettede om katastrofen i 1923, hvor han havde set turistdamperen fra Sild for fuld damp sejle hen over fenner og markhegn i nærheden af Emmerlev. Fortalleren var jysk og historien god. Men det slog mig, at uanset dens rigtighed var der noget helt elementært spændende $i$ den barokke tanke om et skib, der bevægede sig på land.

Selv når det er en illusion, virker det. Min barndomsegn ved Næstved var så frodig og idyllisk, at det nærmede sig det kedsommelige. Men pludselig kunne man se en søgående fragtdamper, der gled hen over den bølgende kornmark. Det var let at abstrahere fra, at der under marken var en kanal på 6 meters dybde fra Ydernæs til Næstved.

Det viser sig også at være et velkendt og meget gammelt motiv i folkesagnene: "Skibet der bevæger sig på land og vand «. ${ }^{1}$ Jules Verne var ikke den første, der forstod at underholde os ved at opfinde et amfibium, som var ubundet af elementerne.

$\mathrm{Nu}$ er det relativt let at undersøge, hvad der faktisk skete i 1923 ved Emmerlev. Foruden muligheden af interviews eksisterer der gamle aviser fra området og stormflodsudvalgets betænkning om katastrofens omfang. ${ }^{2}$ Det lader sig også gøre at efterprøve mange mindre dramatiske situationer med skibe på land, f. eks. vort xldste dampskib i drift, "Hjejlen «s slabning ad Gudenåen og over landevejen til Remstrup å i året 1861. ${ }^{3}$ Også skibsslæbninger i 1700-tallet kan man sikkert kontrollere, som eksempelvis Karl XII's aktion un- 
der belejringen af Frederikssten i 1717. Han lod fartøjer trække helt fra Strømstad til Iddefjord. For den tekniske side af sagen stod den ejendommelige Emanuel Swedenborg, i sin samtid lige kendt som "mechaniker« og religiøs mystiker. ${ }^{4}$

Går vi længere tilbage $i$ tiden, begynder vi ikke at kunne skelne klart mellem fantasi og virkelighed. Allerede Christian IV's »orlogsskib på Skanderborg sø", hvor han som barn skulle have lært sømandskab, er det svært at udtale sig om. I et par århundreder blev denne $i$ sig selv usandsynlige historie troet af historikerne. Men så påviste Troels-Lund, at Christian som barn og ung næesten ikke havde opholdt sig i Skanderborg. Altså et indirekte bevis. ${ }^{5}$

\section{Skibe på land}

Drejer det sig om middelalderen, er vi næsten ude af stand til at efterprøve de mange beretninger om skibe på ruller, $i$ kanaler og på søer. Vi står alene med de farverige fortællinger, og vi savner tit viden om skibstyper og mulige niveau- og vandstandsændringer. Hertil kommer, at beretningerne ofte er snævert knyttet til spændende skildringer af berømte slag.

Lad os begynde med, hvad der nok er en ren skipperskrøne. Den kendes fra 1. årh. e. Kr., da den romerske tekniker og militærteoretiker, Frontinus, skrev et værk om krigskunsten. Heri beretter han om, hvordan spartanerne engang blev indesluttet $i$ deres fjenders havn Piræus ved Athen. Men Lysander, spartanernes snedige feltherre, undslap med flåden ved at lade sxtte hjul under skibene og transportere dem over land til den nærmeste anden havn, Munychia. ${ }^{6}$ Det er formentlig denne historie, der får en ekstra krølle i den russiske *Nestorkrønike* vedrørende årene 6412-6415, dvs. 904-907 efter vor tidsregning. Her drejer det sig om Olég, der forskrækker grakerne til at overgive Byzans (vore dages Istanbul) ved at lade sætte hjul under sine skibe og således både fra søsiden og fra landsiden at komme strygende for fulde sejl imod den belejrede by. ${ }^{7} \mathrm{Nu}$ var det svenske vikinger, der gik under betegnelsen n rus* $i$ vikingetiden, og selv i 1100-tallet, altså henimod sagaskrivernes og Saxos tid, var der nære forbindelser med Rusland. Vi behøver blot at tænke på den byzantinske stil i Valdemarstidens kirkekunst; ja, selv navnet -Valdemar« kommer fra Rusland. Valdemar den Stores (1131-82) 


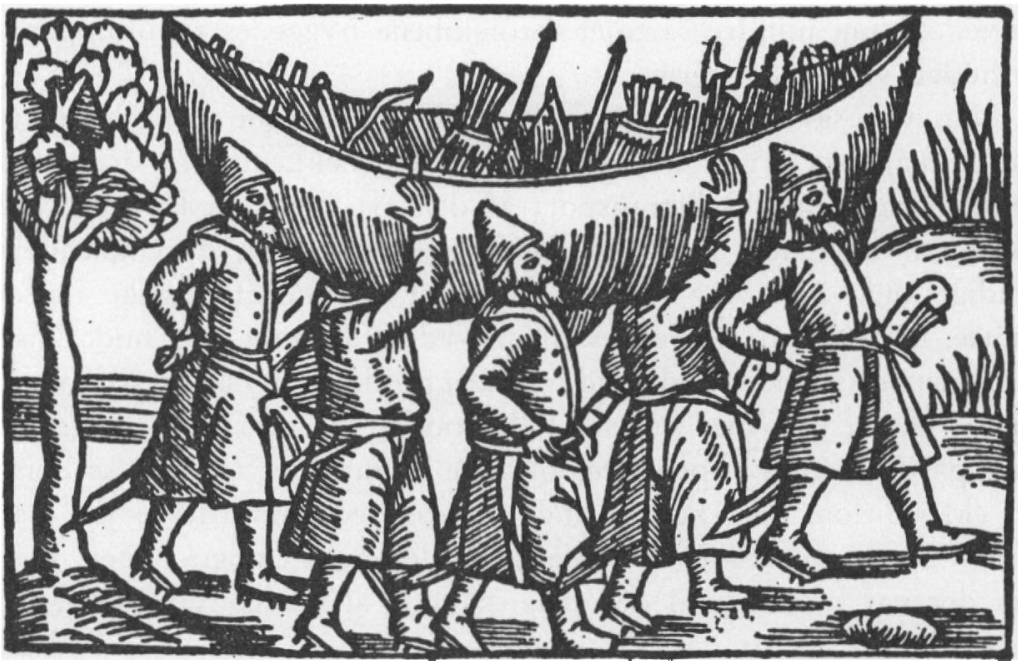

Fig. 1. Russere berer en let båd. Tegning $i$ den svenske biskop Olaus Magnus' bog om de nordiske folks bistorie (1555).

oldefader på mødrene side var storfyrst Vladimir II. Om Olég, hvis nordiske navn var Helge, findes en hel samling af anekdoter, af hvilke mange kan genfindes hos islandske sagaskrivere og hos Saxo, nu tillagt hjemlige helte fra historien og sagnhistorien. ${ }^{8}$

Hvad skal vi da sige, når vi hører om, hvordan man trillede omkring på landjorden med datidens krigsskibe i Skandinavien? De fleste oplysninger har vi fra et område, hvor man allermindst skulle have ventet det: de norske fjelde. ${ }^{9}$ Det, der lokkede til slæbningen, var søslag på de store indsøer $\mathrm{i}$ landet. "Mjøsen er så stort et vand, at det er næsten som havet «, siger Sverres saga. Hertil skal kong Sverre i slutningen af 1170 'erne have flyttet skibe fra Randsfjord, dvs. over $50 \mathrm{~km}$ ad en vej, "hvor folk aldrig før var faret med skibe ", hedder det.10 Men de fleste krigsoperationer af denne art skal være foregået $\mathrm{i}$ Håkon Håkonssøns tid (1217-63), stadig i forbindelse med borgerkrige. Der berettes om talrige skibsslæbninger mellem fjorde og søer, og den militære værdi deraf var ifølge sagaerne ofte tvivlsom. ${ }^{11}$ Til fordel for at tro på $i$ alt fald nogle af beretningerne taler dels den omstændighed, at kilderne er omtrent samtidige med hændelserne, dels at det overalt, hvor skibenes størrelse er nævnt, 
drejer sig om mindre fartøjer. Storskibene byggedes i slutningen af perioden ved selve søerne.

Når man skal vurdere pålideligheden af sådanne fortællinger fra krigssituationer, så er det i grunden tankevækkende, at den måske mest usandsynlige skibstransport af den art fandt sted i året 1915! Ikke i Norge, men i Afrika. Det var på den tid, da englænderne stadig sang »Britannia rule the waves«; selv de afrikanske indsøer måtte, mente man, henregnes til de "ydre farvande" og underkastes den britiske flåde. Imidlertid var det lykkedes tyskerne, tilsyneladende endog kun med en enkelt kanonbåd, at skaffe sig herredømmet på Tanganyika-søen. Det britiske admiralitet forberedte derfor en ekspedition, der skulle bringe to armerede motorbåde fra Cape Town gennem urskove, over bjerge og sletter til Congo-floden, hvorfra der var jernbane til den belgiske side af Tanganyika-søen. Skibene slrbtes af to damplokomobiler, okser og indfødte. Ledelsen havde en britisk, meget ekscentrisk søofficer, hvis selvkomponerede uniform indbefattede et lændeklæde og elegante tatoveringer. De indfødte var betagede af ham. Transporten lykkedes virkelig, og den var så fantastisk, at »flådens « tilsynekomst kom helt bag på tyskerne. Men ledelsen var sådan, at det britiske admiralitet bagefter knap vidste, om man skulle stille søofficeren for en krigsret eller erklære ham for momentant sindsforvirret. Man valgte det sidstnævinte. Hvis ikke hele denne historie havde været bygget på arkivmateriale, forsynet med fotografier og omfattet interviews med endnu levende ekspeditionsdeltagere, ja så ville man vel ikke have troet på den. ${ }^{12}$

Men tilbage til vikingetiden. De mest pålidelige efterretninger om skibstransporter over land stammer fra Rusland, og til forskel fra Norden drejer det sig ikke om krigsbegivenheder, men om handelsveje med slæbesteder. Trafikale behov, flodsystemer og troværdige kilder forenes i dette område. ${ }^{13}$ De svenske handelsfolk og vikinger fulgte en rute fra Ladoga-søen frem til Volga og ad denne til det Kaspiske Hav. Her er vi dog mindre godt underrettet om slæbestederne end på den anden rute: ad Dnjepr til Sortehavet. Det er omgåelsen af en rakke farlige vandfald syd for det nuværende Dnjepropetrovsk, vi har viden om gennem den byzantinske kejser Konstantin Porfyrogénnetos' værk fra ca. 950.14 Der skelnes mellem større skibe, "karaboi « (ordet kommer formentlig af "karve«, en nordisk skibstype) og slaviske "monóxyloi «. Det sidste ord betyder på grask 
"gjort af én stamme«, og disse småbåde blev båret på nakken rundt om svært passable vandfald. Man var altså nødt til at anvende lettere både end de sxdvanlige. Noget lignende synes man at have gjort langt ned i tiden, som det $f$. eks. fremgår af Olaus Magnus' fortællinger og tegninger fra 1500-tallets Finland og Rusland. ${ }^{15}$ (Fig. 1).

Også i Frankrig skal vikingerne have slæbt skibe; men her er vi tilbage $i$ skildringer af felttog. Der er grund til skepsis i hvert fald over for nogle af beretningerne om vikingerne. Den mest berømte skibsslæbning skal have fundet sted under belejringen af Paris i 888. $\mathrm{Da}$ frankerne sparrede Seinen, »trak de (vikingerne) skibene mere end totusind skridt (ca. $3 \mathrm{~km}$ ) over den tørre jord ", for at omgå spærringen, »en bedrift, der var uhørt ikke blot for vor, men også for tidligere slægter «. Beretningen er Regino af Prüms, ${ }^{16}$ og skønt samtidig med begivenhederne, må hans udsagn ifølge Niels SkyumNielsen anses for tvivlsomt. Skibsslæbningen forekommer nemlig ikke $i$ andre af tidens udførlige kilder, og desuden gentages historien af Regino på en stereotyp måde for året $890 .{ }^{17} \mathrm{På} \mathrm{den} \mathrm{anden} \mathrm{side} \mathrm{skal}$ man nok heller ikke være for kritisk over for muligheden af skibsslæbninger, hvis man accepterer vikingernes flytning af vældige belejringstårne under Paris' bymure. ${ }^{18}$ Nogle forskere mener, at der noget tidligere (år 861) fandt en skibsslæbning sted på en $3 \mathrm{~km}$ lang strækning mellem floderne Epte og Seine $i$ en situation, hvor frankernes konge, Karl den Skaldede, havde fået den idé at betale nogle af vikingeskarerne til at bekæmpe de andre. ${ }^{19}$

En ejendommelig historie foreligger om frankernes egne skibsslæbninger. På et felttog i 810 imod maurerne i Spanien medførte de småskibe, så de kunne sætte over floderne. Hver båd var ifølge kilden delt i fire dele, og hver af delene blev lagt på to muldyr eller heste. Med sig havde man naturligvis nagler, beg, voks og "værk « (stuppa) til at txtne bådene med, når de samledes og sattes $\mathrm{i}$ vandet. ${ }^{20}$

Det ville føre for vidt, hvis hvert enkelt eksempel på rullende fartøjer i vikingetidens Europa skulle fremstilles og gennemgås kildekritisk. På den anden side tror jeg, at de vigtigste beretninger er nævnt ovenfor. Skibsslæbning synes at have været mindre hyppig, end de mest fantasifulde kilder lader formode. De var fortrinsvis knyttet til militære begivenheder, ikke mindst overraskelsesmanøvrer. Som regulært led i etablerede handelsruter har man vistnok kun haft slæbesteder ved de russiske flodsystemer. Slæbesteder med sær- 
lige konstruktioner har jeg ikke stødt på fra middelalderens Europa. I oldtiden havde man derimod den berømte "diolkos « ved Korinth (6. årh. f. Kr.), som kendtes fra kilderne, men forst blev fundet og udgravet i 1950'erne. ${ }^{21}$

Vi kan imidlertid ikke forlade problemet om skibsslæbninger uden at omtale Danmark som helhed (altså bortset fra Ejder-Sli-området, der skal specielt behandles). I grunden er der forbavsende fă historiske efterretninger $\mathrm{i}$ betragtning af, at de mange lavtliggende landtunger skulle indbyde til slxbning. Derimod vrimler det med stednavne, som tyder på trækning af skibe op på land eller over land: Drag og Drej (Dragør, Dragsholm, Dragsmur, Drejø, osv.).22

Den kendteste skibsslxbning fremkaldte for hundrede år siden en heftig debat imellem danske historikere. Det drejede sig om, hvorvidt Harald Hårdråde under sit plyndringstogt til Limfjorden i 1060'erne var undsluppet de danske forfølgere ved at lade sine skibe trakke ud $i$ Vesterhavet - eller ved at sejle derud. Ca. 150 år efter begivenheden hører man nemlig af Saxo, at åbningen ved Agger-Harboøre nu var sandet til. Hele tre problemer måtte diskuteres: naturforhold, kildekritik og slabesteder $\mathrm{i}$ almindelighed. ${ }^{23} \mathrm{Hvad}$ det sidstnæwnte angår, så troede Kr. Erslev på historien om Olég, der »sejlede" mod Byzans fra landsiden, og på andre af de krigsanekdoter, der er gengivet ovenfor. I grunden er det mærkeligt, når man tænker på, at Erslev senere skulle blive banebryder for kildekritikken i dansk historieforskning. Men den da kun 20-årige historiker blev også tilbagevist af sin $x$ ldre fagfælle, Johs. Steenstrup. Han ville ikke afvise, at vikingerne lejlighedsvis havde flyttet deres skibe mindre strækninger over land; men han betonede stærkt, at det må have været mindre både. Ja, han ville endog retfærdiggøre Olég-myten ved at antage, at det har drejet sig om både af den type, som bares på skuldrene omkring de farlige vandfald ved Dnjepr. ${ }^{24}$

I øvrigt er Steenstrup gennemgående den af datidens historikere, som forholder sig mest kritisk over for usæedvanlige skibstransporter til lands og til vands. Således har han rammet en pal igennem de gamle, men sejt fastholdte spekulationer om, at Susån skulle have været sejlbar helt til Sigersted i nærheden af Ringsted. Teorien hvilede dels på Saxo, dels på misforståelser af senere kilder. ${ }^{25}$

Diskussioner af denne art fra det danske område viser klart, at 
man må foretage mindst tre forskellige undersøgelser: (1) en kildekritisk, (2) en naturgeografisk og (3) en skibshistorisk undersøgelse. $\mathrm{Og}$ dette er ofte en så kompliceret kombination, at f. eks. det meget debatterede Limfjordsproblem nxppe kan siges at have fundet sin endelige løsning endnu. ${ }^{26}$

\section{Skibe i kanaler}

Så længe der var tale om slxbning af skibe på land, spillede efterretningerne om krigspuds en stor rolle. Med kanaler er man til dels ude over problemet vedr. den type anekdoter. Større jordarbejder umuliggjorde overraskelsesmomentet - og berøvede historieskriverne lejligheden til at fortalle en god historie. Kanaler har dog altid kunnet tjene til langsigtede forbedringer af den strategiske position. I Norge lod Håkon Håkonssøn grave en kanal ved Tønsberg for at forkorte søvejen til distrikterne ved Oslofjorden, ifølge sagaen "således at man nu kan sejle med kogger, hvor man før næppe kunne sejle med småbåde . ${ }^{27}$ Såvel begivenheden som beretningen er fra 1200-tallet, og her ser vi måske årsagen til, at vi har så få meddelelser om kanaler før denne. Behovet for kanaler opstår især, når skibstyperne er blevet tilstrækkelig store, og dette hænger naturligvis atter til dels sammen med en øget efterspørgsel efter massevarer, der skal transporteres over lange afstande (korn, fisk o.s.v., men naturligvis

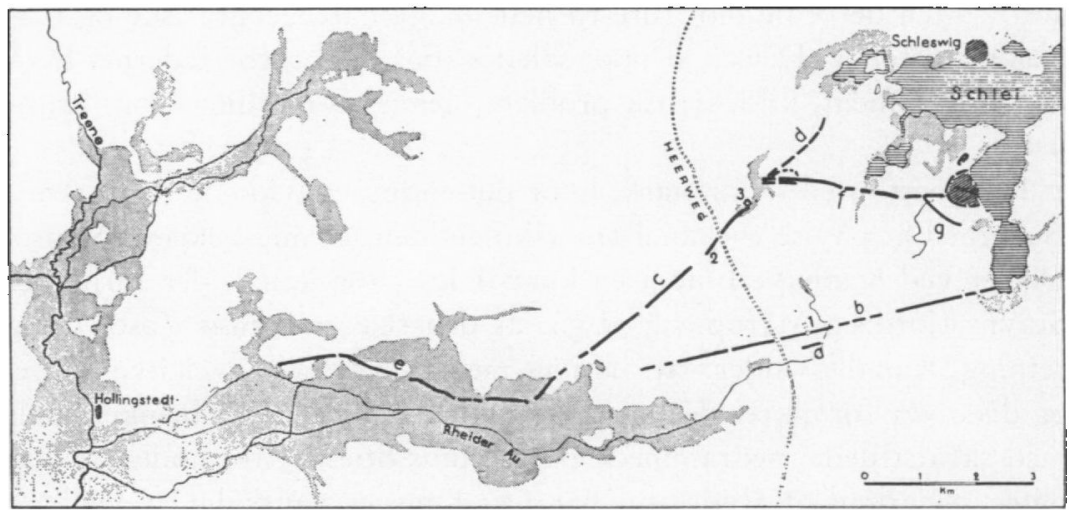

Fig. 2. Danevirke og Rejdeåmosen. a Korte Kovirke. b Kovirke. c Hovedvold. d Nordvold. e Krumvold. f Forbindelsesvold. g Forvold. - 1 Fldre Harvejsport i Kovirke. 3 Borgevold (Tyraborg). 
også tropper). I 1200-tallet var man godt på vej til at skabe tungere skibe med større lasteevne. ${ }^{28}$

Der findes lokaliteter rundt om i Nordeuropa, hvor man mener at kunne påvise kanaler, men med vekslende og usikre dateringer. Et af problemerne for datidens kanalbyggere synes at have været af teknisk art. Kanalerne førtes ofte gennem lavtliggende, sumpede områder imellem flodsystemer. Dette gjorde ikke alene gravningen vanskelig, men også afstivning og vedligeholdelse i form af oprensning. Hertil kommer, at man ikke kan bygge skibskanaler $i$ områder med store niveauforskelle mellem vandsystemerne uden brug af sluser. Sådanne kendes først fra senmiddelalderen.

Der er derfor ikke noget overraskende $i$, at vi næsten intet hører om kanaler $\mathrm{i}$ vikingetiden. Et af de få projekter blev berømt alene, fordi det blev en stor fiasko. Karl den Store ønskede at forbinde to bifloder til Main og Donau af rent militære grunde. Han førte ved denne tid krig mod avarerne i Balkanområdet. Foretagendet indledtes $\mathrm{i}$ året 793 under opbud af »en mængde mænd «. Arbejdet mislykkedes, og de Frankiske Rigsårbøger forklarer det med, at jorden var så sumpet, at alt, hvad man gravede op om dagen, sank tilbage igen om natten. Og imens blev Karl mere optaget af at nedkæmpe oprørere og fjender andetsteds $\mathrm{i}$ sit vældige rige. ${ }^{29}$

Man kunne naturligvis give sig til at undersøge en række lokaliteter i Holland, Nordtyskland og i den norske og svenske skærgård, hvorfra der haves meddelelser om vellykket og mislykket kanalbyggeri. ${ }^{30}$ Men det ville blot føre til helt lokale naturgeografiske og tekniske drøftelser. Det er jo ikke således som med slæbestederne, hvor der er et alment, kildekritisk problem, nemlig fortællingen om krigslisten.

Det eneste sted i Danmark, hvor det endnu er lykkedes med sandsynlighed at påvise en kanal fra vikingetiden, er mig bekendt Samsø. Der er ved Kanhave fundet en knap $1 \mathrm{~km}$ lang kanal, der forbinder Stavns fjord og Mårup vig, d.v.s. at den skærer Samsø $\mathrm{i}$ øst-vestlig retning. Kanalens sider var afstivet med tre egefjale over hverandre, og disse var forankret dels med trænagler, der gik ind i brinken, dels med skråtstillede, nedrammede pæle. Hans Stiesdal formoder, at kanalen på grund af flydesand har været meget vanskelig at vedligeholde. ${ }^{31}$ Samsingerne har selv en mundtlig tradition om, at de under svenskekrigene i 1600-tallet af en indespærret svensk flåde blev tvun- 
get til at grave kanalen, så fjenden kunne slippe ud af Stavns fjord.32 Dette er fejlagtigt, både ifølge kulstof 14-dateringer og på grund af kanalens ringe vanddybde. I øvrigt véd vi, at Samsø og Stavns fjord spillede en væsentlig rolle $\mathrm{i}$ den tidlige middelalder; Vilh. la Cour vil ikke udelukke, at kanalen tidvis har varet $\mathrm{i}$ brug fra ca. 800 til op i 1100-tallet. . $^{39}$

Man må ikke undervurdere vikingernes evne til at lave store konstruktioner i træ, såvel over som under vandlinien. Tidligere nævnte vi de store belejringstårne ved Paris. I 1972 udgravede man ved Danevirkes hovedvold en vældig egetræssubstruktion, der havde holdt volden $» f l y d e n d e$ i sumpen ved Borgevold (Tyraborg). Andetsteds $i$ landet er arkæologer beskæftiget med vikingernes vej- og brobygningskunst, som også synes at have været mere imponerende end hidtil antaget.

\section{Mellem Slien og Trene}

Som hovedindtryk efter ovenstånde oversigt over situationen med skibe på land og i kanaler, må man fastholde, at vel synes intet umuligt; men man må gå meget forsigtigt til værks. Har man ladet sig inspirere af historiske kilder eller gamle kort, må der i første omgang sættes ind med en kildekritisk behandling.

Fra området ved Slesvig haves vistnok kun én historisk beretning om skibsslæbning på land, og det er den sædvanlige krigslist. I begyndelsen af $1150^{\prime}$ 'erne, under borgerkrigen mellem Sven, Knud og Valdemar, havde Knud søgt ned til friserne på den holstenske vestkyst og vundet dem for sig ved at love skattelettelse. $\gg D$ a rygtet om hans (Knuds) hjemkomst nåede Sven, lod han jyderne stille med rytteri og sendte bud efter sjællændernes og skåningenes flåde. Nogle af skibene sendte han til Slesvig og lod dem trække over land helt over til Ejderen, for at fjenderne ikke skulle slippe bort ad den vej; men det kostede ham mere end det gavnede ham «. Dernæst drog Sven imod den nyligt anlagte befæstning ved Milde å. I Saxos originalversion lyder passagen: »Sveno, reditus ejus opinione accepta, Jutis in equitatum digestis, a Sialandis et Scanis classem asciscit. Ex qua nonnullas naves Sleswici subductas ad Eidoram usque solo tenus pertrahendas curavit, ne ea pars hostibus elapsui foret. Qux res ei impendio magis quam usui fuit « ${ }^{34}$ Historien genfindes $i$ to andre, lidt 
yngre kilder fra 1200-tallet. I Knýtlinga saga hedder det næsten enslydende: "En er Sveinn konúngr spurði petta, dró hann pegar her saman, ok fór til Heiðabœjar, hann hafði skipalið, ok (dró) par skipin fra Slétti yfir til Hýlíngstaða á Fríslandi; varò par orrosta mikil, aðr hann fengi unnit Mildinborg ${ }^{35}$ Den vigtigste forskel er, at sagaen anvender navnene Hedeby, »Slétti o og Hollingsted. Endelig finder vi i Rydårbogen: "Quo audito, Sveno cum tota expeditione Danorum venit Sleswic, et adductis inde navibus per terras usque Huchlstiath, predictum castrum Mildeborh obsedit. . .«. ${ }^{36}$ Her har vi atter en form af navnet Hollingsted.

Ligheden mellem de tre kildesteder er så stor, at man må oversætte dem med omtrent samme ord, og dette gxlder større dele af kilderne i det omhandlede tidsrum. At de tre kilder er indbyrdes afhængige, er der ingen, som mere er i tvivl om. Spørgsmålet er, om meddelelserne i Knýtlinga saga og Rydårbogen på en eller anden måde går tilbage til Saxo, eller der findes en fælles, ukendt kilde for dem alle tre. Begge synspunkter har været hævdet. ${ }^{37}$

$\mathrm{På}^{\circ}$ denne baggrund er den forsigtigste tolkning, at Knýtlinga og Rydårbogen ikke har haft mere kildestof end Saxo, hvad den pågxldende episode angår, ud over et større lokalkendskab. De har været $i$ stand til at indsætte stednavne ${ }^{38}$ og fjerne den usandsynlighed, at skibene skulle være slæbt helt over til Ejderen, som Saxo skriver. For en lokalkendt årbogsskriver i Ryd kloster ved Flensborg fjord har det åbenbart været en rimelig tanke, at skibene er slæbt til Hollingsted. Dette stemmer også med, at man i Slesvig byret fra ca. 1200 har en særlig afgift for købmænd, der kører med vogn fra Slesvig til Hollingsted: "Pro quolibet plaustro eunte Hubelstath quatuor denarios ${ }^{39}$.

Tilbage står problemet om, hvorvidt det er den gamle historie fra Grakenland, nu henlagt til Sydslesvig. Det er der faktisk intet, som tyder på, hverken $\mathrm{i}$ udformningen eller $\mathrm{i}$ motivet til at bringe historien. Navnlig tjener den langt fra til glorificering af Sven, der heller ikke hørte til Saxos helte. Begivenheden fremtræder nærmest som lidt af en tåbelighed. Hvis man har den mindste tillid til de gamle kilder, når de beretter om begivenheder, der kun ligger et par menneskealdre eller tre tilbage i tiden, må man altså fæste lid til historien.

Der er grund til at hxfte sig ved, at Saxo bruger udtrykket solo og Rydårbogen per terras, d.v.s. på eller over land. Der er altså her, 
så lidt som i Slesvig byret, tale om nogen kanal eller sejlads på Rejde å i 1100-tallet.

For teorien om en kanal er det især en helt anden type kildestof, som har været inddraget. Det er de xldste kort, som fremstiller Danevirke og Sydslesvig tilstrækkelig detaljeret. Olaus Magnus, den svenske biskop, udgav i 1539 et kort over Skandinavien, og tyve år senere fremstilledes det $æ$ ldste, kendte specialkort over Slesvig-Holsten. Det sidstnævnte udkom som et træsnit ved matematikeren Marcus Jordanus, der her afbildede sit hjemland (fig. 3 og 4).

Olaus Magnus viser med sit kort en selv efter datidens forhold forbavsende mangel på matematiske kundskaber. Pudsigt nok antager Danevirke både ved signatur og størrelse helt groteske dimensioner.

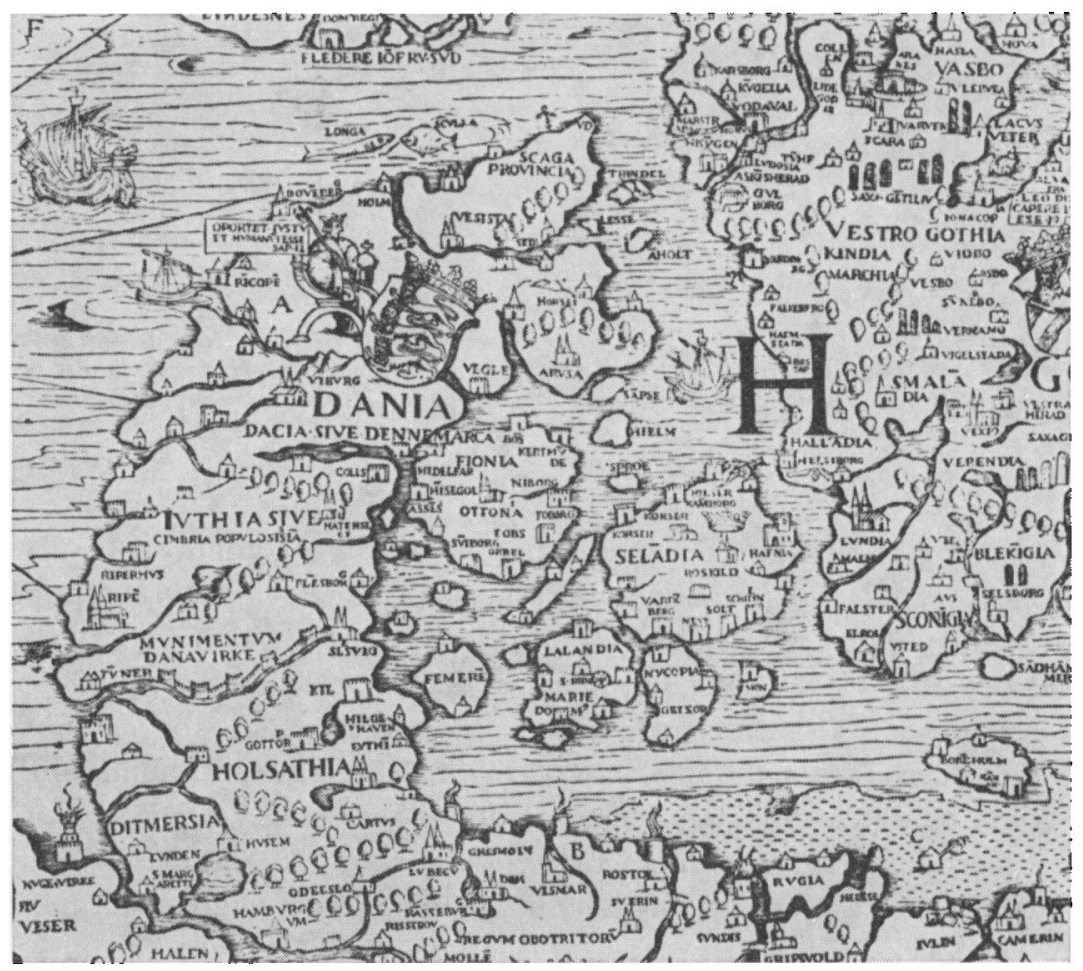

Fig. 3. Udsnit af det store af 9 blade sammensatte Nordenskort, som blev udgivet $i$ Venezia 1539 under titlen .Carta Marina, udført af den svenske biskop Olaus Magnus. 


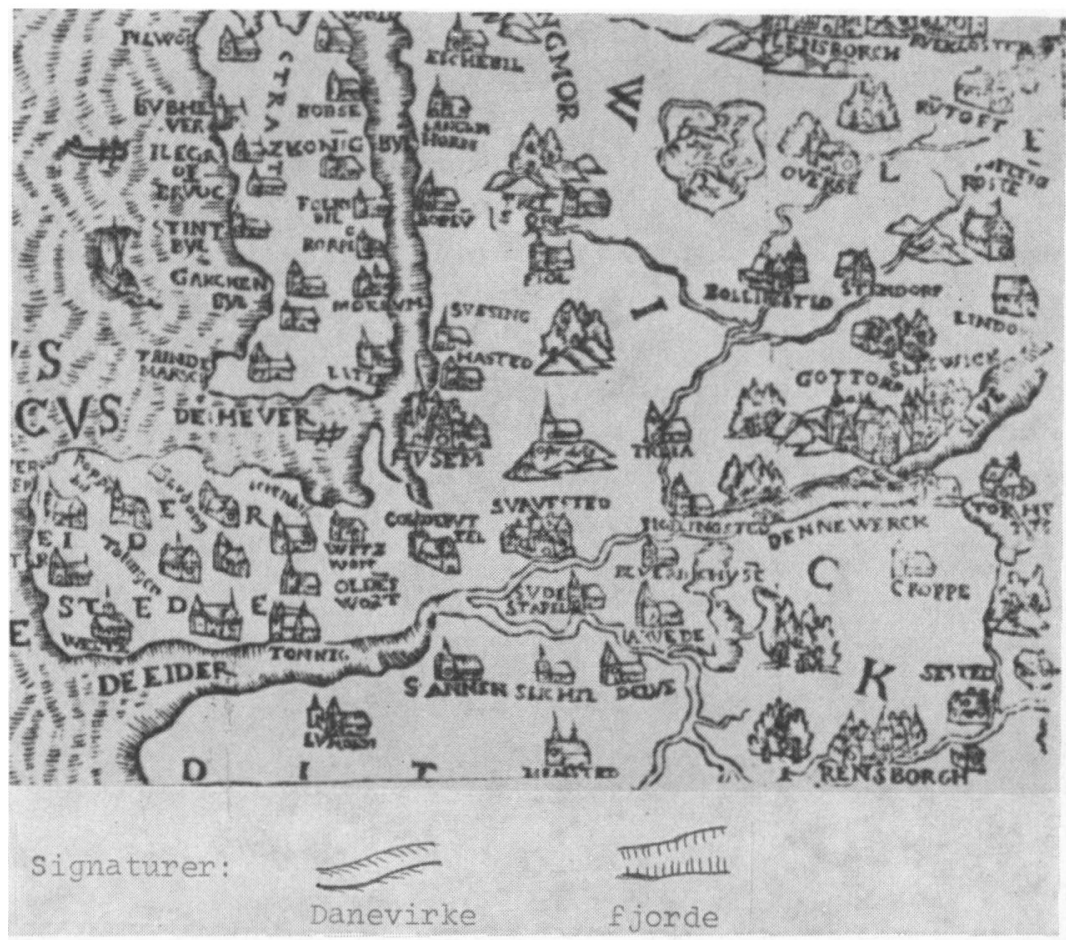

Fig. 4. Udsnit af Marcus Jordanus' kort over Slesvig og Holsten. Det er ikke hans forste og eneste kort, men det er det aldste, vi kender. Oprindelig trasnit og trykt hos Joachim Löw $i$ Hamburg 1559. Bemark vold-og fjordsignaturerne.

Ved murens fod flyder en strøm, der enten er en voldgrav eller Ejderen. "Vandløbet " kan ikke overraske. Ganske vist hører vi intet om en vandfyldt grav ved Danevirke, da de slesvigske lokalhistorikere dukker op i 1500-tallets slutning, og det må betragtes som en ren konstruktion. To tankegange var nemlig nærliggende for en lærd mand uden lokalkendskab. For det første optræder fænomenerne "vold « og "grav « of te sammen, når der er tale om fæstningsværker. For det andet vidste man to ting: Danevirke drkkede den danske sydgrænse, og Danmarks grænse var Ejderen. Den fejlagtige slutning, at Danevirke lå langs Ejderen, var allerede draget i de Frankiske Rigsårbøger, hvor det under året 808 meddeles, at »dette fæstningsværk dækkede hele Ejderflodens nordlige bred «. ${ }^{40}$ Det er muligvis en 


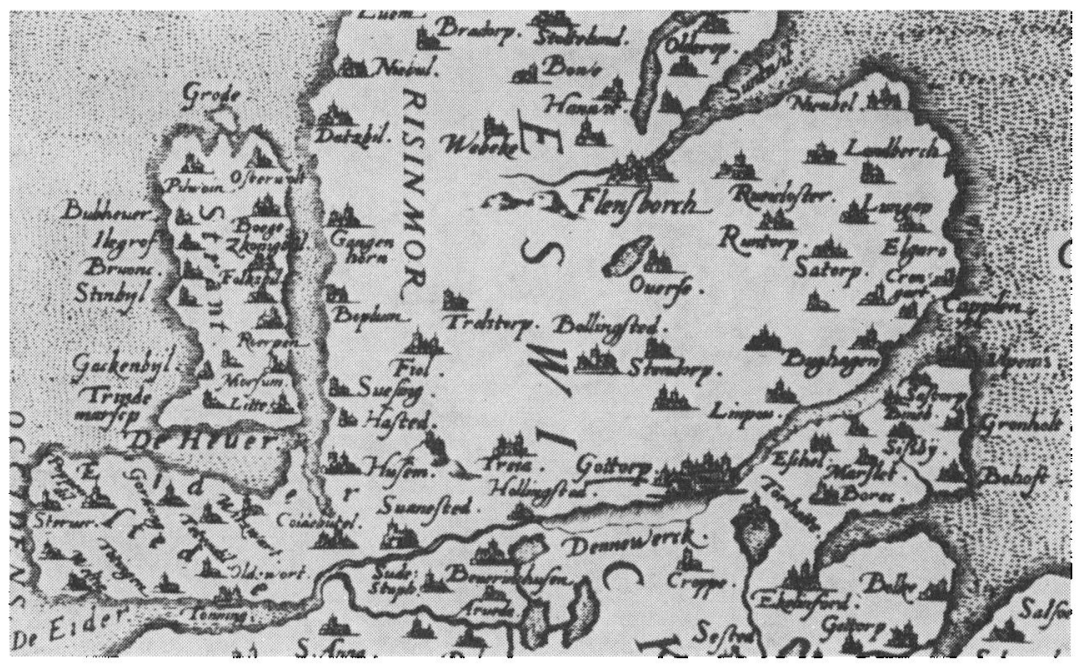

Fig. 5. En omtegning af Marcus Jordanus' kort. Udgivet $i$ Gerardus de Jode: Speculum orbis terrarum (1578). Pà dette kort har tegneren misforstået Jordanus' voldsignatur; Danevirke (Dennewerck) ligner narmest en sø, uden at der dog er anvendt signaturen for vand (smlg. Jordanus' kort overfor).

forveksling af lignende art, som ligger bag det ejendommelige forhold, at navnet »Danevirke« i 1424 og muligvis senere også optræder som en betegnelse for en »grav« mellem Ejderen og Levenså, altså ved selve grænsen. ${ }^{41}$.Undertiden benævnt »Sønder-Danevirke«. Der er altså flere grunde til at afvise Olaus Magnus' kort.

Af en langt bedre kvalitet er Marcus Jordanus' kort, men der findes flere udgaver af det. Foruden det ældste træsnit fra 1559, som kun kendes $i$ ét eksemplar, er der to mere velkendte, trykte gengivelser, nemlig i de Jodes "Speculum orbis terrarum « (1578) og Ortelius' »Theatrum orbis terrarum « (1579) (se fig. 5-6).42 Man bemærker, at Danevirke har forskellig signatur på disse tre kort. På det ældste er der klart tale om en vold, på det næste nærmest om en sø og på det sidste en rivende strøm. Sammenligningen viser tydeligt, at de to yngste udgaver beror på misforståelser af ikke lokalkendte folk. Dermed falder det kartografiske grundlag for en kanalteori ved Danevirke bort, da man ikke finder stotte $i$ andre samtidige eller yngre kort, snarere tværtimod. 


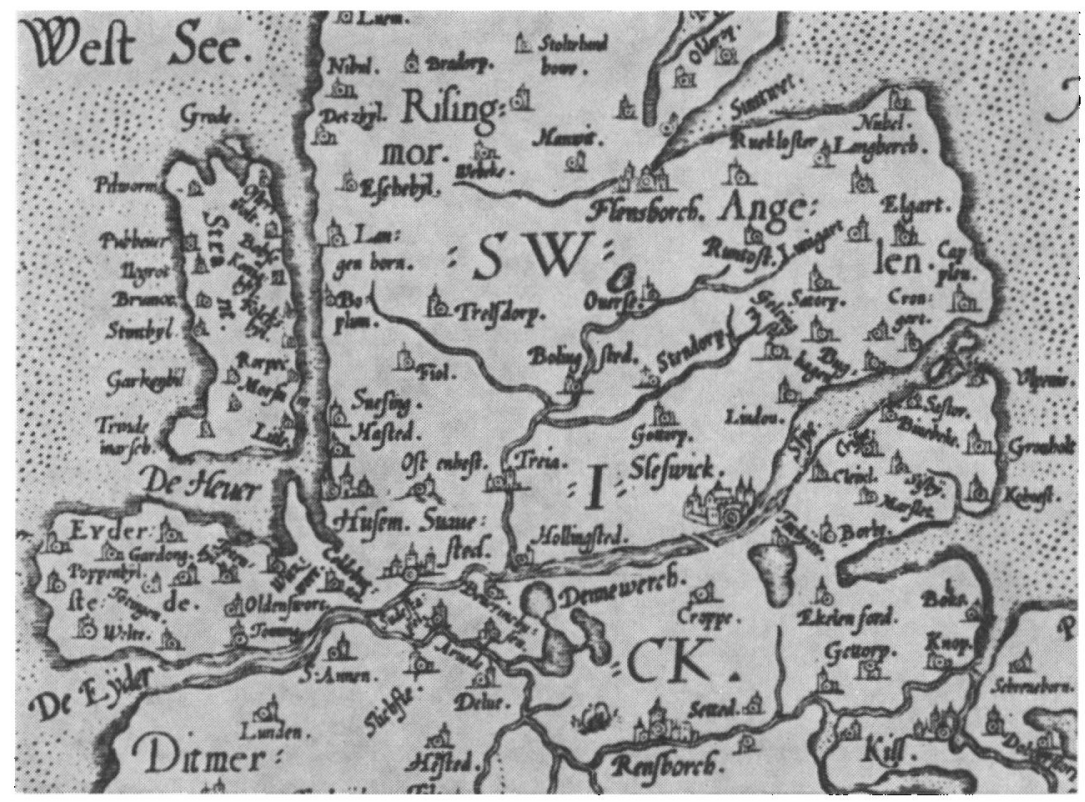

Fig. 6. Endnu en omtegning af Marcus Jordanus' kort. Udgivet i A. Ortelius: Theatrum orbis terrarum (1579). Nu er misforstaelsen fuldstandig. Danevirke (Dennewerch) er blevet til en strøm ligesom Ejderen. I vrigt er kortet et ganske smukt bandkoloreret kobberstik.

Kanal- og slabestedsteorier omkring Danevirke

(1) Lokalbistorikere.

Der findes en overordentlig righoldig lokalhistorisk litteratur om Slesvigegnen, og den er kun til dels blevet kritisk sammenstillet. ${ }^{43}$ Den begynder med hertug Adolfs kansler Adam Tratziger, der et år før sin død i 1584 skrev en topografi om Slesvig, og traditionen har man fortsat til vore dage, naturligvis med en stigende grad af videnskabelighed.

Det er ikke lykkedes mig at finde kanalteorien hævdet for $\mathrm{i}$ begyndelsen af 1700-tallet, men da sker det til gengxld på brillant vis. Det er i nogle notater, som prxsten Ulrich Petersen efterlod sig ved sin død i 1735. En del deraf publiceredes på tysk i 1756 og mere udførligt $\mathrm{i}$ dansk referat år $1800 .{ }^{44}$ Hans udgangspunkt er tre overvejelser: For det første, at Kovirke "mere må prises for sin lige linie 
end for sin særlige forsvarsevne" (smlg. fig. 2); navnet "Kograben " (den tyske betegnelse for volden) peger også i retning af dens egentlige karakter, siger han. For det andet antager han med udgangspunkt i navnene Store og Lille Rejde, at der her engang har været "red f for skibe. For det tredie mener han, at Kovirke engang har nået frem til vandet $\mathrm{i}$ Rejdeåns dal. Alt dette fører ham til at antage, at større skibe har kunnet løbe op ad Rejde å, før diger og sluser ved Frederiksstad ændrede vandstandsforholdene. Mindre fartøjer har desuden kunnet fortsætte ad "Kograven « til Selk nor.45 Allerede Ulrich Petersens tyske udgiver tilføjer dog her en note, som indledes med et $»$ Aber nein! $«$, hvorefter der kommer en rakke gode grunde til ikke at antage, at denne tørre grav, som udmunder på et for sejlads ufordelagtigt sted ved Selk nor, nogensinde har været farbar for fartøjer. Færre forbehold havde Ulrich Petersens danske udgiver, P. F. Suhm, men han refererer til gengæld også Petersens egne visioner for en økonomisk ophjælpning af området i 1700-tallet. "Petersen meener, at det endnu tilovers værende af denne Vold (denne gang Danevirkes hovedvold, smlg. fig. 2) kunde være af største Nytte, hvis der til Handelens Udbredelse blev anlagt en Canal fra Treenen til Slien, da Murens Grundvolde kunde forhindre Jordens Udtrædelse“. Man kunne på en gang skabe en skibskanal, afvande enge og få »den skiønneste Leilighed til Møllers og Fabrikers Anlæg «. ${ }^{46}$ Her forenes fortid og fremtid i ét stort lysende perspektiv.

Ideen om den gamle sejlvej, i hvert fald for Rejde å's vedkommende, kan følges i den senere tyske lokalhistorie, f. eks. hos den lokalpatriotiske præst i Hollingsted, J. R. F. Augustiny (1852). Endnu så sent som i 1930 citeres uddrag af Petersen i Philippsens Danevirke-fører. ${ }^{47}$

Det kan indskydes, at en moderne stednavneforsker som Wolfgang Laur antager, at navnet "Reide kommer, ikke af red, men af oldsachsisk briod, der betyder tagrør. ${ }^{48}$ I ovrigt må man formode, at åens danske navn, Spangebæk, er ældst. Navnene Store og Lille Rejde er nxppe fra vikingetiden.

Tanken om Rejde å og Kovirke som en sejlvej har imidlertid også haft en mere lokal, folkelig udformning. En mand, født 1851 i Kurborg ved Danevirke, fortalte Andreas Lorenzen, at man $\gg i$ helt gamle dage« kunne trakke små skibe ad Kograven. De blev trukket af stude eller køer, deraf navnet "Kograven". Pudsigt nok inddrager 
meddeleren som et vidnesbyrd om troværdigheden den i 1908 fundne bådkammergrav syd for Hedebys halvkredsvold.

Andreas Lorenzen accepterede alt dette og tilføjede med henblik på tvivlere, at han havde fået teorien om Kovirke stadfæstet, da han ved læsning af den ovenfor omtalte Augustiny var blevet opmærksom på, at kong Sven havde ladet slæbe skibe fra Hedeby til Hollingsted i 1153. "Hvor kunne det foregaa andre Steder end fra Hedeby Nor ad Kograven? «, spørger han. ${ }^{49}$

Man må betegne alt dette som på en gang folkelig og lærd spekulation.

\section{(2) Handelshistorikere.}

Delvis uafhængigt af den ovennævnte lokale slesvigske tradition har en række forskere ud fra almindelige overvejelser antaget, at overførsel af skibe har spillet en væsentlig rolle for Slesvig/Hedeby som handelsby. Der har i reglen været tale om trækning af skibe på tørt land mellem Hedeby og Hollingsted. Således hos C. Daenell, W. Vogel, E. Arup, H. Matthiessen, A. Schück og P. Boeles, for blot at nævne et udvalg af de kendteste forskere. ${ }^{50}$ Specialundersøgelser af terrænet og af kilderne med særligt henblik på problemstillingen ved Slesvig tør man ikke regne med, at disse handelshistorikere har foretaget.

(3) Danevirke- og Hedebyforskere.

Hvad har nu de arkæologer og historikere ment, som gennem længere tid har arbejdet med både kilderne og terrænet ved Danevirke og Hedeby? Generelt har hypoteserne om slæbevej eller kanaler spillet en meget ringe rolle. Ikke fordi man ikke har kendt til Saxos og Rydårbogens fortzlling eller de gamle ideer om en kanal; man må ganske enkelt ikke have fundet grundlag for en seriøs argumentation. Dette gælder Chr. C. Lorenzen, August Sach og H. Handelmann i forrige århundrede. Ved århundredskiftet Sophus Müller og Carl Neergaard, og i nyere tid Vilh. la Cour, Herbert Jankuhn, Roar Skovmand og Kurt Schietzel. De danskere, som har gravet ved Danevirke siden 1962, har vistnok heller ikke (hidtil) vist nogen speciel interesse for teorien..$^{51}$ Det må dog understreges, at ingen af alle de nævnte forskere - for så vidt de overhovedet har udtalt sig - ligefrem har forkastet tanken om skibes overførsel som noget normalt $i$ 
vikingetiden. De mest positive udtalelser, jeg har set eller hørt, stammer fra Roar Skovmand og Herbert Jankuhn. Førstnævnte siger: "... hvis man ... fulgte Trenen op til Hollingsted, var der kun 16 $\mathrm{km}$ over Land til Byen ved Halvkredsvolden. Saa maatte man enten slæbe Skibene over Land eller omlade Varerne to Gange - hvilken af Delene man har foretrukket, ved vi ikke $\alpha_{0}^{52}$ Jankuhns holdning er mere nuanceret, men herom senere.

Der er imidlertid tre Danevirke-interesserede, som er gået meget varmt ind for teorier, som indbefatter såvel kanalfart som stedvis transport på ruller. Disse tre er den svenske handelshistoriker Elis Wadstein (Göteborg), den tyske historiker Friedrich Frahm (Hamburg), der i øvrigt navnlig er kendt for sit arbejde med Slesvigs retshistorie, og den danske lokalhistoriker Aage Lauritsen (Ulbølle på Fyn). Deres teorier er ikke identiske, men deres metoder har en vis lighed.

Wadstein kom i 1925 til det resultat, at "ifall, såsom möjligt är, den vanliga transportvägen för skeppen gått längs Kovirke, hava fartygen vid passerandet av de vattenfyllda delarna av befästningslinjen helt enkelt satts ned $i$ vattnet, varvid Kograv på ett par kortare stycken även kunnat tjänstgöra som skeppskanal «.53 Dette lyder jo ganske spagfærdigt. Imidlertid er det blot konklusionen på en lang, elegant og suggestiv optakt om frisernes handelsveje og alle beretningerne om slabesteder i Europa. Der er også en række specielle oplysninger om Kovirke. Man læser om de gamle (ikke beviste) antagelser om kasteller ved Kurborg og Selk nor og den fejlagtige tolkning af navnet "Kograben «. På dette sidste punkt udbygger han påstanden om en grav med henvisning til, at Danevirke $i$ året 974 kaldes en fovea, altså en fordybning eller grav. ${ }^{54}$ Her er blot det at indvende, at fovea ligesom fossa og fossatum (latinske udtryk for voldgrav o.a. grave) anvendes $i$ flæng sammen med eller $i$ stedet for vallum (vold) i kilder fra middelalderen og senere. Når man bygger en fæstningsvold, er det jo nærliggende at gøre sig arbejdet lettere ved at tage jorden nedenfor. D.v.s. at der samtidig bliver en grav, der ydermere kan gøre det vanskeligt at bestige volden for mulige fjender. I øvrigt har vi al grund til at formode, at den fovea, der omtales i 974, ikke var Kograven, men Danevirkes hovedvold.55 Den vaklende sprogbrug konstateres også i senere kilder. Således lader den Danske Rimkrønike (1495) Harald Blåtand sige formentlig 
om hovedvolden: "Saa lod jeg kastæ ther op en graff fran sleswigh oc saa tijl westher haff « $^{56}$ det står $i$ øvrigt $i$ et grotesk afsnit, hvor digteren med skadefryd fortæller, at tyskerne fik smæk i deres whale «. Hvis man tror, at det er fordi "grav« rimer bedre på "hav «, end "vold" ville have gjort, kan man studere f. eks. Arrild Huitfeldts krønike (1603): „De Frantzoske Historier, formelde, denne Grøfft (Danevirke) at vere skeed udi Keyser Caroli Magni tide, og Kong Godefreds i Danmarck. Men tør skee den gamle Grøfft tør vere forfalden, oc nu fornyet igien «. ${ }^{57}$ Her tænkes på dronning Tyra Danebods vold, og den betegnes i samme afsnit som »Grofft oc Vold « eller "Voldsted «. En meget morsom illustration af sprogbrugen får man ved at sammenligne Saxos betegnelser for Tyras vold med hans oversætter, Anders Sørensen Vedels (1575). Inden for blot to linier lykkes det Saxo - til dels for den sproglige variations skyld - at kalde Danevirke vallum/ fossa, agger og munimentum terrenum (vold/grav, vold og jordvirke). Vedel derimod anvender $\mathrm{i}$ dette afsnit konsekvent ordet "Vold “. ${ }^{58}$ Kort sagt: man kan ikke slutte fra sådanne sproglige detaljer i gamle kilder til konkrete, byggetekniske træk. Kanalteoretikerne har imidlertid gjort det, fra Ulrich Petersen til Aage Lauritsen. ${ }^{59}$

Som sagt var Wadsteins konklusion i 1925 forholdsvis forsigtig, og man får ingen anelse om, hvor meget han i de foregående år havde sat ind på at bevise sin kanalteori. Af Hedebyarkivet på Gottorp slot fremgår det imidlertid, ${ }^{60}$ at han havde formået museumsdirektør Fr. Knorr til i 1921 at lade foretage opmålinger og udgravninger ved Kovirke for at efterprøve teorien om en kanal, bygget af friserne. Ja, han sendte tilmed gode svenske kroner til det inflationshærgede Tyskland for at få gennemført projektet. Men hans energi og tålmodige brevskriveri stod $\mathrm{i}$ omvendt forhold til resultaterne. Knorr konstaterede, at Kovirke mod vest havde ophørt på det tørre land, at den $\mathrm{i}$ sit forløb næppe havde kunnet være vandfyldt, og at der ikke var spor efter afstivninger i graven. Jorden er stærkt sandet, og afstivning havde været påkrævet, hvis voldgraven skulle have tjent som kanal. ${ }^{61}$ Wadsteins ord i 1925 viser altså, at han på trods af disse resultater ikke lod sig overbevise, omend han udtrykte sig forsigtigere end tidligere.

Allerede fem år efter var den nxste kanalteoretiker klar med en afhandling: Friedrich Frahm. ${ }^{62}$ Han havde taget så meget ved lære 


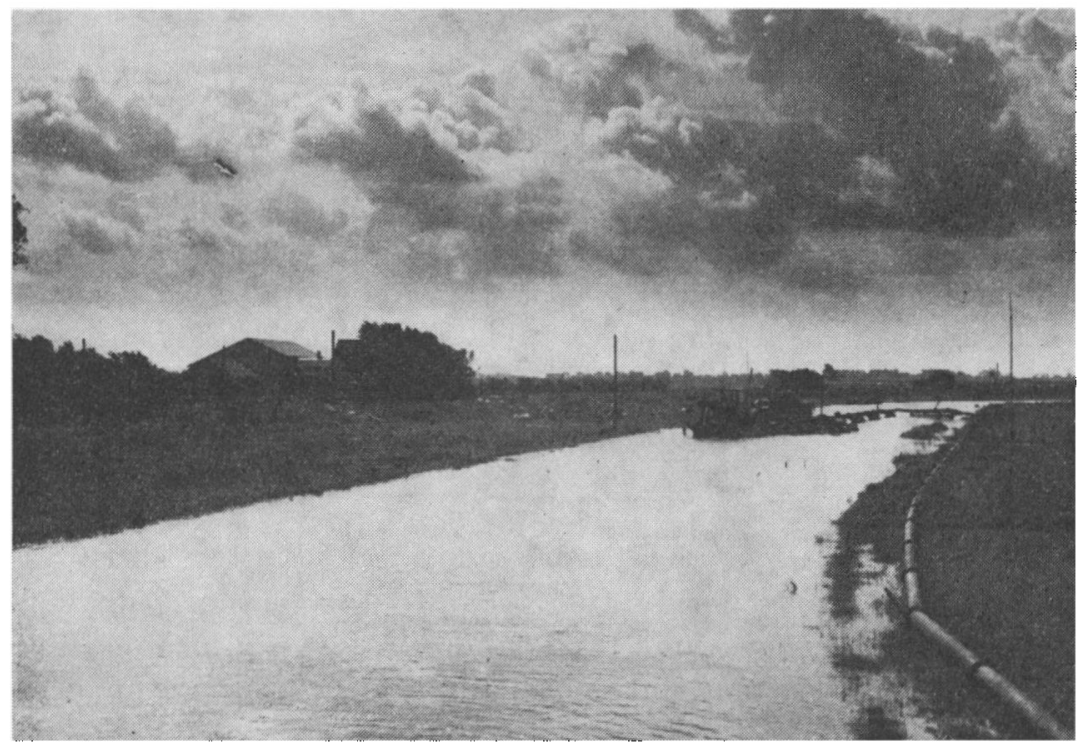

Fig. 7. Trene ved Hollingsted, set fra nord. Til venstre under og for laden fandt man den gamle bosettelse. Sandpumperen og rorene viser, at der foregdr en af de oprensninger, som $i$ tidens lab har bragt mange fund for dagen (1962).

af sin forgænger, at Kovirke ikke nævnes som kanal. Til gengæld lægger han overordentlig stor vægt på de generelle historiske omstændigheder, som tyder på skibsoverførsler. Dels har han en udførlig behandling af fortællingen om Sven i 1150'erne (smlg. ovenfor), dels prøver han at vise, at Hollingsted allerede i 500-tallet spillede en væsentlig rolle. Han sammenstiller navnet "Huhelstath " (Hollingsted) fra ca. 1200 med en sagnkonge, Hugleik, der muligvis er identisk med frankiske kilders Chochilaicus, som var en nordisk viking, der døde på et togt $\mathrm{i}$ begyndelsen af 500-tallet. Det ville føre for vidt at gå nærmere ind på disse udredninger. Han siger som forklaring på denne Hollingsteds formodede betydning, at de samme grunde, som forte varehandelen via Ejderen og Slien i stedet for uden om Skagen, også måtte gøre det nærliggende at transportere skibene samme vej. Topografisk lancerer han - vistnok som den første - formodningen om, at den vestlige del af hovedvolden, der går under navnet krumvolden, slet ikke er noget forsvarsværk, men en dæmning. Desuden 
henviser han til den gamle idé om »Rejde« som »red « for skibe og til, at Kovirke på Johs. Mejers kort fra 1649 når helt frem til krumvolden. "Det ville $\mathrm{i}$ hvert fald fortjene en alvorlig efterprøvelse, om ikke vikingeskibene i den ældste tid med deres ringe dybgånde er blevet slæbt uden last til voldkrumningen ved Rejde. Selv Danevirke synes os ikke ganske sikret mod mistanke om, at $\mathrm{i}$ det mindste de store voldgravsanlæg foran Valdemarsmuren samtidig har været benyttet til transport af de tomme både. ${ }^{63}$ D.v.s. en vældig opdæmmet sø i Rejdeådalen og kanaler langs hovedvold og forbindelsesvold til $\mathrm{He}-$ deby.

Nu var det ikke længere Knorr, der stod for udgravningerne, men Herbert Jankuhn. Det var ham, der blev opfordret til den »alvorlige efterprøvelse «. Jankuhn undersøgte dels Hollingsted, dels supplerede han Knorrs gamle gravning ved Kovirkes vestlige afslutning. I krumvolden og hovedvolden blev der også lagt snit, men her som led $\mathrm{i}$ den almindelige undersøgelse af Danevirke $\mathrm{i}$ disse år. Man havde heldet med sig i Hollingsted, idet man fandt rester af både en bosættelse og en voldgrav. Fundene kunne dateres til vikingetid og tidlig middelalder, så man måtte slutte, at bosættelsesperioden dxkkede såvel Hedebys som det nordlige Slesvigs blomstringstid. Men de fleste fund var gjort i opmudret materiale fra Trenen, så det var ikke muligt at sige meget om bopladsens art udover, at den har haft et beskedent omfang. En del af den fundne keramik er måske heller ikke bopladsfund, men stammer fra potter, der er gået itu under transporten og derefter blevet kastet overbord. ${ }^{64}$ Hvad voldgraven angår, så konstaterede man en meget uregelmæssig fordybning og undersøgte den kun ved et enkelt, blot $1 \mathrm{~m}$ bredt og $12 \mathrm{~m}$ langt snit, der af Jankuhn betegnes som "problematisch im ganzen gesehen «. Han mente dog at kunne slutte, at krumvolden her havde haft en grav (ved vejen fra Hollingsted til Dørpsted). ${ }^{65}$ Ved Kovirkes vestende kom han til samme resultat som Knorr: denne vold havde aldrig nået ud, hverken til krumvolden eller til de lavereliggende dele af Rejdes ådal. ${ }^{66}$ Disse $\mathrm{i}$ grunden beskedne resultater hindrede imidlertid ikke Frahm $\mathrm{i}$ at opretholde sine teorier. Lige så lidt som Wadstein lod han sig overbevise, ja fundene i Hollingsted opfattede han nærmest som en stor sejr. Vel under indflydelse af tidens sprog - det var i begyndelsen af 2. Verdenskrig - mente han i Hollingsted at have bidraget med et »flankeangreb «, som kunne lette arkxologernes »frontalan- 
greb « i Hedeby. End ikke Kovirkes forbindelse med krumvolden følte han det nødvendigt helt at opgive tanken om. ${ }^{67}$

Herbert Jankuhns holdning til problemet om overførsler af skibe har været åben og nuanceret. Han har næppe nogensinde været tilhænger af kanalteorierne, ${ }^{68}$ men han har $i$ flere bøger antydet den mulige eksistens af en slæbevej over tørt land, dog uden nærmere lokalisering. ${ }^{69}$

Som den hidtil sidste "kanalteoretiker " skal Aage Lauritsen omtales. Hans artikel fra 1971 om "Volden og den glemte vej« er lang og spændende skrevet. Man kan ikke lade være med at beundre hans friske og umiddelbare engagement. Men han synes heller ikke at være belastet af viden om sine forgxngeres frugtesløse anstrengelser igennem tre århundreder på at finde den såkaldte "glemte « vej. ${ }^{70}$

Medens Wadstein betragtede Kovirke som en kanal på visse strækninger, og Frahm inddrog hovedvold-forbindelsesvold-linien i sin kanalteori, så satser Lauritsen i første omgang på krumvolden og det "Korte Kovirke" (se fig. 2). Men i øvrigt er det vanskeligt at sammenfatte hans teori for kanalens forløb, dels fordi han opererer med talrige alternativer, dels fordi han (navnlig henimod artiklens slutning) nærmest boltrer sig $\mathrm{i}$ historisk prægede hypoteser. Hvad der interesserer mest ud fra den synsvinkel, jeg har valgt her, er hans metode. Han anvender (1) historiske kort og skriftlige kilder, (2) stedfundne udgravninger og (3) topografiske studier.

Hvad angår kortene, så tager han de kort, han kender, for gode varer. Således det fejltegnede kort af Marcus Jordanus, hvor Danevirke er et vandløb (se ovenfor). ${ }^{71}$ Desuden et kort af Johs. Mejer (1651), hvor der løber en tværvold ned fra voldknækket ved Kurborg. ${ }^{72}$ Det var ellers ikke mere end et århundrede efter Mejer, at man erkendte, at mange af hans tværvolde ikke eksisterede, ${ }^{73} \mathrm{og}$ ikke nok med det: Mejer selv har tegnet kort over Danevirke, hvor netop den "vold «, som Lauritsen er så glad for, slet ikke findes. ${ }^{74} \mathrm{I}$ øvrigt har Vilh. la Cour med rette peget på Lauritsens ukritiske brug af Johs. Mejers kort $i$ et tidligere arbejde. ${ }^{75}$ Hertil kommer vidtgående tolkninger af de skriftlige vidnesbyrd. Det gxlder Rydårbøgernes meddelelse om skibsslæbningen i $1150^{\prime}$ erne; overførslen af skibe accepteres, men der ses bort fra, at den fandt sted "over land (per terras, se ovenfor)..$^{76}$ Man hører ikke om nogen kanal her, så lidt som i den ikke meget yngre Slesvig byret. En af Snorres sagaer, der be- 
retter om Danevirke, tolkes teknisk til påvisning af dæmninger, ${ }^{77}$ og Huitfeldts brug af ordet "Grøfft « for Danevirke inddrages, omend med et spørgsmålstegn (smlg. ovenfor). ${ }^{78}$

Udgravningsresultaterne rummer of te mulighed for flere tolkninger, og her vælger Lauritsen bestandig den, der passer bedst med kanalteorien. Navnlig er der grund til at fremhæve, at Fr. Knorrs gamle gravninger ved Hedebybxkkens løb gennem halvkredsvolden (1913) er højst usikre, ligesom flere andre af Knorrs undersøgelser. ${ }^{79}$ Angående det "Korte Kovirke " må det nævnes, at Lauritsen ikke har inddraget den undersøgelse i 1940, som bedre end de tidligere kunne pege på muligheden af en gammel Hærvejsspærring og ikke en kanal.80 Jankuhns snit i krumvolden og de vanskeligheder, der knytter sig til det, er omtalt ovenfor under behandlingen af Frahm. Den lange diskussion om tømmeret i krumvoldens substruktion skal jeg undlade at tage stilling til; først med de seneste års dendrokronologiske undersøgelser af træet vil vi formentlig få et mere sikkert grundlag for en opfattelse. ${ }^{81}$

Aage Lauritsens topografiske studier er utvivlsomt det mest originale $\mathrm{i}$ hans arbejde. Her er vurderingerne også langt mere kritiske og nuancerede, end når det gælder de historiske kilder og udgravningsresultaterne. Han når frem til en hel række muligheder for kanalløb, hvor han ganske vist foretrækker nogle frem for andre, men dog vist egentlig holder alle muligheder åbne. For den østlige (højtliggende) del over imod Hedeby arbejder han med ikke mindre end 7 tænkelige forløb. ${ }^{82}$ Og ude vestpå $i$ Rejdes ådal opererer han, idet han har højdekurver som grundlag, med mindst to kanalløb. Skønt han ellers til stadighed bygger sine hypoteser på, at kanalen har undgået niveauforskelle, så er han dog ikke utilbøjelig til at tro, at den også kan være løbet langs hovedvoldens nordside til Danevirke sø. Denne principløshed har fået en af hans kritikere til at bemærke, at "når Aage Lauritsen så let forlader grundlaget for $\sin$ teori, kan han ikke vente, at andre vil behandle det med større respekt ${ }^{83}{ }^{83}$ Lauritsen svarer hertil, at "når der nu synes at være en mulighed for en kanallinie dér (ved hovedvolden), må det jo nævnes, uanset hvor godt eller dårligt det passer sammen med det forud omtalte ${ }^{84}{ }^{84}$ Dette er naturligvis en korrekt og prisværdig holdning. Der er blot en hage ved den: Lauritsen har i sin artikel arbejdet med så mange hypoteser, at det formentlig ville være uoverkommeligt både okonomisk og arbejdsmæs- 
sigt at efterprøve dem alle - hvis det skulle være nødvendigt. Hertil kommer, at man selv dér, hvor man eventuelt graver, må regne med ikke altid at kunne nå frem til éntydige resultater. Jeg har selv prøvet at grave efter voldgrave $i$ et af de sumpede områder ved Danevirke og kender også andre, der har ubehagelige erfaringer. Det vil altså sige, at en teori med mange hypotetiske alternativer $i$ en rum tid kan vxre uimodtagelig for enhver afvisning begrundet ved udgravninger. Jeg mener på ingen måde, at Lauritsen bevidst har villet fremsætte en i praksis næsten dirkefri teori. Men arbejder man med mange alternerende hypoteser $i$ et område, der tilmed er svært at udforske, så vil resultatet let blive dette: anskuelser, som ikke er modbevist og som derfor må stå til troende - vel at mærke for den, som vil tro.

Men der er også andre problemer $\mathrm{i}$ forbindelse med Lauritsens teori. Mellem det højeste og det laveste punkt $i$ hans kanaler er der mindst 20 meter, og denne højdeforskel er ikke jævnt fordelt. Lauritsen erkender, at vi savner viden om sluser fra denne tidlige tid, så han må forudsætte en anden form for»højdeskift «. Afhængigt af, hvilken af hans mange formodede linieføringer, der er tale om, bliver det til mere end en halv snes slæbesteder mellem niveauerne. Dette får ham atter til at antage, at varerne er blevet omladet til vogne og kørt, mens man har slæbt skibene den besværlige vej til lands og til vands. ${ }^{85}$ Der har $i$ sandhed skullet gøres et stykke arbejde, også efter at kanalen var bygget.

Det ser virkelig ud til, at Lauritsens kanalteori er en kulmination af over tre hundrede års skiftende kanalteoretikeres arbejde ved Danevirke. Både $\mathrm{i}$ antal og $\mathrm{i}$ omfang overgår hans hypoteser langt, hvad forgængerne har kunnet præstere.

Hvis jeg selv skulle udtale et ønske om undersøgelser, så måtte det blive dette, at man startede en systematisk udforskning af terrænet imellem og foran voldene. Det ville være af værdi både for en vurdering af deres militære betydning, og navnlig ville man måske kunne finde den "landevej «, som må have løbet fra Hedeby til Hollingsted. $\mathrm{Da}$ jeg for en halv snes år siden lagde søgegrøfter langs forbindelsesvolden og foretog en undersøgelse af jorden under selve volden, fik jeg materiale, som viste $x$ ldre vejspor, lynghede $\mathrm{m} . \mathrm{m}^{86}$ Sideløbende med landskabsstudier burde man $\mathrm{i}$ arkiverne undersøge de ændringer, som dyrkning, markinddeling og afvanding har forårsaget $i$ århun- 
dredernes løb. Om ikke for andet, så for at undgå fejlslutninger under studiet i marken. Manglen på sådanne arkivstudier præger også Lauritsens topografi.

\section{Sammenfatning}

Det var en lang vandring i selskab med slæbestedsforskere og »kanalteoretikere«. Måske vil man stille mig spørgsmålet om, hvad jeg i grunden selv mener. Har vikingerne virkelig sejlet eller rullet skibe mellem Slesvig/Hedeby og Hollingsted? Jeg tror ikke, at der i dag kan gives noget sikkert svar. Alt taget $i$ betragtning hælder jeg nærmest til Herbert Jankuhns forsigtige opfattelse: Vi kan ikke udelukke, at man har kunnet komme et stykke op ad Rejde å med mindre skibe, men i øvrigt har man sandsynligvis slæbt sådanne skibe over land - men i ukendt omfang og med ukendt hyppighed.

Jeg må imidlertid gøre opmærksom på, at det faktisk ikke har været selve dette komplicerede problem, jeg har ønsket at behandle. Det har mere været teorierne om det. Synsvinklen fremgår af undertitlen: »Myter, spekulation og forskning omkring et Danevirke-problem «. Det er tankevækkende, at mennesker med vidt forskellig uddannelse og under brug af metoder, der for en del er identiske, gennem tre århundreder er vendt tilbage til en og samme grundtanke: skibet, der bevæger sig til vands og til lands. Al modstand fra såkaldt autoriserede forskere er blevet afvist. "Kanalteoretikerne « udgør en standhaftig og tapper brigade.

Nogle vil måske finde det underligt, at en sådan interesse, der lugter mistænkeligt af psykologi, har kunnet få mig til i adskillige år at indsamle materiale om sagen. Så jeg må nok hellere gå til bekendelse: jeg har selv engang hørt til de tapre forkæmpere for en variant af teorien. I mine første studieår udtænkte jeg de mest sindrige apparater, ved hvis hjxlp friserne og vikingerne havde trukket skibe over bakke og dal. Først da jeg kom under behandling af forskere som Vilh. la Cour og Herbert Jankuhn, fortonede apparater og skibe sig som fantasifostre. Til sidst var jeg bragt til det punkt, hvor jeg kun kunne forestille mig et eneste skib passere halvøen ved Hedeby. Efter en lang arbejdsdag under gravningerne ved Danevirke, så jeg $\mathrm{i}$ aftentågen et skib, der gled lydløst langs volden: Den flyvende Hollænder. 


\section{NOTER}

1. Nordisk Kultur IX (Folkeviser, Folkesagn og Folkeeventyr) (Kbh. 1931) s. 206, 229 og 272.

2. Dagbladet Vestkysten $31 / 8$ og $1 / 9$ 1923. - Betæenkning afgivet af Stormflodsudvalget af 1923 (Kbh. 1924).

3. M. Lebech: Hjejlen. Danmarks aldste dampskib og sejladsen paa Himmelbjergsøerne (Kbh. 1961) s. $86 \mathrm{f}$.

4. Generalstaben: Bidrag til den Store Nordiske Krigs Historie IX (Kbh. 1932) s. $268 \mathrm{ff}$. - Jfr. biografier over E. Swedenborg.

5. Troels-Lund: Christian den Fjerdes Skib paa Skanderborg Sø I (Kbh. 1893) s. $7 \mathrm{ff}$.

6. Frontinus: Strategemata I, V, 7. Lettest tilgængelig i: Frontinus: Kriegslisten. Lateinisch u. deutsch von G. Bendz (Berlin 1963) s. 36. - Smlg. P. F. Subm: De Gamles Krigs-Skole, aabnet ved de gamle Skribenteres Frontini, Polyani, Eliani og Arriani Oversættelser I-II (Kbh. 1847).

7. The Russian Primary Chronicle, Laurentian Text, ed. S. H. Cross and O. P. Sherbowitz-Wetzor (1953) s. 64.

8. Ad. Stender-Petersen: Den russiske litteraturs historie I (Kbh. 1952) s. $71 \mathrm{ff}$.

9. Alm. oversigt, $A$. W. Brøgger og H. Shetelig: Vikingeskipene, deres forgjengere og etterfølgere (Oslo 1950) s. 241-48.

10. Sverres saga, kap. 12. Fornmannasögur b VIII (1834). Overs. Norges Kongesagaer, 1914-utg., ved G. Storm og A. Bugge, III (Kristiania 1914) s. 21. - A. Holtsmark: Sverres saga. En tale mot biskopene (Oslo 1961) s. 39.

11. Hákonar saga Hákonarsonar. Fornmannasögur IX (1835). Overs. Norges Konges. (note 10) IV, s. 57-295. - A. Holtsmark: Hăkon Håkonssons saga (Oslo 1964).

12. P. Shankland: The Phantom Flotilla. I da. overs. „Flåde over land (Kbh. 1968).

13. H. Arbman: Svear i österviking (Sthlm. 1955) s. 72-96.

14. Constantin Porphyrogenitus: De administrando imperio, ed. G. Moravcsik and R. J. Jenkins I (Budapest 1949) s. 51 og 61. - A. Karlgren: Dneprfossernes nordisk-slaviske Navne (Kbh. Univ. Aarsskr. 1947). - K. O. Falk: Dneprforsarnas namn i kejsar Konstantin VII Porfyrogennetos' De adm. imp. (Lunds Univ. årsskr. 1951).

15. Olaus Magnus: Historia de gentibus septentrionalibus ... (Rom 1555) X, 10; XI, 7-9 og 12; XX, 2 (s. 338, 364 ff, 369 og 699).

16. Reginonis abbatis Prumiensis chronicon. MGH 5, I (Pertz) s. 599 og 601. Da. overs., N. Skyum-Nielsen: Vikingerne i Paris (Kbh. 1967) s. 69 f. - Jobs. Steenstrup: Normannerne II (Kbh. 1878) s. 231 accepterede skibsslæbningen.

17. N. Skyum-Nielsen (note 16) s. 69 f., noterne 175 og 181.

18. Abbon: Le siège de Paris par les Normands, éd. et trad. par H. Waquet (Paris 1942). - N. Skyum-Nielsen (note 16) s. 90-109.

19. F. Lot: La grande invasion normande de 856-862 (Bibliothèque de l'Ecole des chartes, 69, 1908, s. 5-62, særlig s. 51 f.) genoptr. i: Recueil des travaux historiques de Ferdinand Lot II (Genève 1970) s. 713-70, særlig s. 759 f. Findes ikke hos Johs. Steenstrup (note 16) s. $172 \mathrm{f}$, men er accepteret af P. H. Sawyer: The Age of the Vikings (London 1962) s. 82 (2. ed. 1971, s. 83) og N. Skyum-Nielsen (note 16) s. 69. 
20. Anonymi vita Hludowici imperatoris c. 15. MGH. SS. (Pertz) II, s. 614. - J. F. Verbruggen: L'armée et la stratégie de Charlemagne (I: Karl der Grosse I, hrsg. H. Beumann, Düsseldorf 1965, s. 420 ff, særlig s. 431 f.).

21. Paulys Real-Encyclopädie der classischen Altertumswissenschaft IX (Stuttgart 1914) s. v. "Isthmos o og Suppl. XI (1968) sp. 534.

22. P. Skautrup: Det danske sprogs historie II (Kbh. 1947) s. 57. - Aa. Houken: Håndbog i danske stednavne (Kbh. 1956) s. $83 \mathrm{f}$.

23. Den $æ$ ldre litt., se $H$. Matthiessen: Limfjorden (2. udg. Kbh. 1960) s. 152 f., n. 8.

24. Kr. Erslev: Harald Hårdråde i Limfjorden (Aarb. f. nord. Oldk. og Hist., 1873 , s. 57-72) s. 67 . - Jobs. Steenstrup: Normannerne I (Kbh. 1876) s. 355 ff.

25. Jobs. Steenstrup: Har Susaa i den historiske Tid været en sejlbar Strom til Sjællands Midte? (Hist. Tidsskr., VII, 6, 1905-06, s. 108-115).

26. $H$. Mattbiessen (note 23) s. 41 mener, at Limfjorden var åben imod vest $\mathrm{i}$ slutn. af 1000-tallet, og han lader det stå hen, hvor Haralds skibsslæbning fandt sted. - Holger Rasmussen: Limfjorden åben og lukket (Turistforen. årb., 1958, s. 9 ff.) og samme: Vel kaldes det tilsammen Limfjorden (Skalk, 1966: 5 , s. $18 \mathrm{ff}$.) mener, at fjorden var lukket i 1000 -tallet, og at der foregik skibsslabning over tangen $\mathrm{i}$ vest.

27. Hákonar saga Hákonarsonar (note 11) kap. 333.

28. O. Crumlin-Pedersen: Cog-Kogge-kaag. Trxk af en frisisk skibstypes historie (Handels -og Søfartsmus. på Kronborg, årb., 1965) s. 117 ff. - Samme: «Skibstyper * (Kulturhist. leks. f. nord. middelalder XI, 1970).

29. H. H. Hoffmann: Fossa Carolina (I: Karl der Grosse I, hrsg. H. Beumann, Düsseldorf 1965, s. 437-53). Kilde: Annales regni Francorum a. 793, MGH. SS. (Kurze 1895) s. 93/95.

30. Smlg. *Kanal«, "Flodregulering og "Hamn* i Kulturhist. leks. f. nord. middelalder.

31. H. Stiesdal: Kanalen der skærer Samsø over (Skalk 1960: 4, s. 6-8).

32. Th. Gravlund: Herredsbogen. Jylland (Kbh. 1930) s. 4.

33. Vilh. la Cour: Danske borganlag I (Kbh. 1972) s. 129.

34. Saxo Grammaticus: Gesta Danorum, ed. J. Olrik \& H. Ræder I (Kbh. 1931), lib. 14, VII, 3, s. 385.

35. Sögur Danakonunga. Knytlinga saga kap. 108, utg. f. Samfund til Udg. af gammel nord. Litt. av C. af Petersens og E. Olson (Kbh. 1919-25) s. 239.

36. Annales Danici Medii avi, ed. Ellen Jørgensen (Kbh. 1920) s. 79 f.

37. C. Weibull: Saxo (Hist. tidskr. f. Skåneland, 6, 1915, s. 179-236). - G. Albeck: Knytlinga (Kbh. 1946) s. 237-340. - Smlg. Anne K. G. Kristensen: Danmarks xldste annalistik (Kbh. 1969).

38. Stednavnet $\rightarrow$ Slètti bet. slette, men er i ovrigt ukendt. G. Albeck (note 37) s. 309, n. 326. - W. Laur: Die Ortsnamen in Schleswig-Holstein (Slesvig 1960) s. 362 .

39. Slesvig Stadsret $\$ 30. Danmarks gamle Købstadlovgivning, ved E. Kroman, I (Kbh. 1951) s. 9.

40. Annales regni Francorum a. 808. MGH. SS (Kurze 1895) s. 126. Om kilden, se H. Schledermann: Slesvig/Hedebys tilblivelse II (Sønderj. årb., 1967, s. 16-21. - Johs. Steenstrup: Danmarks Sydgrænse (Kbh. 1900) s. 3-8.

41. Sdr. Danevirke nævnes forste gang i vidneudsagnene til den lensproces, hvormed Erik af Pommern i 1424 søgte at skaffe sig herredømmet over Sønderjylland (Script.rer. Dan., ed. Langebek, VII, 1792, s. 404, 411, 413 og 421.) $H$. 
Handelmann (Zeitschr. d. Ges. f. Schlesw.-Holst. Gesch. 13, 1883, s. 7) fandt en geografisk "Confusion* i udsagnene og mente, at der snarere var tale om Kovirke. Imidlertid er stedfastelsen klar nok, som vist af Vilh. la Cour: Danevirke og Kampene paa vor Sydgrænse, (Kbh. 1917) s. 238-42. Smlg. også Jobs. Mejers *Landscheide* på dette sted (C. Danckwerth: Newe Landesbeschreibung der zwey Herzogthümer ..., 1652, tab. XXIIX). I dag er der vistnok på gr. af kanalgravning intet af denne eventuelle vold at se, smlg. Soph. Müller og C. Neergaard: Danevirke (Nord. Fortidsm. I, Kbh. 1903) s. 277.

42. Alle de omtalte kort fra 1500-tallet, N. E. Norlund: Danmarks Kortlægning I (Kbh. 1942) Pl. 9, 16 og 29, 1-2.

43. Vilh. la Cour: Historikeren og Sønderjylland I (Kbh. 1941), der dog kun omfatter tiden frem til ca. 1650.

44. Ulrich Petersens historische Nachricht von der berühmten Cimbrischen Landwehre, dem sog. Kohgraben und grossen Walle Dännewerk im Herzogthum Schleswig (I: J. Fr. Noodts Beiträge zur Erläuterung ... der Herzogthümer Schleswig und Holstein, II. Bd., 4. Stück, 1756, VII, s. 558-603). - P. F. Suhm: Historie af Danmark VII (Kbh. 1800) s. 672-95.

45. Noodts Beiträge (note 44) s. 564-74. - Smlg. til navnene, W. Laur: Wallnamen und Stellenbezeichnungen am Danewerk (Beiträge z. Schlesw. Stadtgesch., 5, 1960, s. 49-69).

46. P. F. Subm (note 44) s. 692.

47. J. R. F. Augustiny: Versuch einer Chronik des Kirchspiels Hollingstedt (Flensborg 1852) s. 24 f., smlg. s. 13. - H. Philippsen: Danewerk-Führer (4. Aufl. Slesvig 1930) s. 58, smlg. dog s. 62.

48. W. Laur (note 38) s. 317.

49. A. Lorenzen: Folkeminder fra Dannevirke-Egnen (Sønderj. Maanedsskr., 20, 1944, s. 215-34) særlig s. 217 f. og smst., 21, 1945, s. 197.

50. C. Daenell: Die Stellung der Stadt Schleswig im frühmittelalterlichen Handel und Verkehr (Zeitschr. d. Ges. f. Schlesw.-Holst. Gesch., 38, 1908) s. 410. -W. Vogel: Geschichte der deutschen Seeschiffahrt I (Berlin 1915) s. 83. - E. Arup: Danmarks historie I (Kbh. 1925) s. 93. - H. Matthiessen: Middelalderlige Byer (Kbh. 1927) s. 19. - A. Schück: De äldsta nordiska stadssamhällena Birka och Slesvig-Hedeby (Nord. Kultur XVIII, Kbh. 1933) s. 6. - P. Boeles: Friesland tot de elfde eeuw (2. druk, Gravenhage 1951) s. $398 \mathrm{f}$.

51. Folgende danskere har gravet ved Danevirke 1962-73: H. Schledermann (1962-63), O. Voss (1969-70), H. Andersen og H. J. Madsen (1970-73). Mindre undersøgelser er foretaget af tyskerne $K$. Schietzel og $H$. Steuer, foruden af flere af medarbejderne ved Landesmus. f. Vor- u. Frühgesch. (Gottorp).

52. R. Skovmand: Vikingetiden (I: Sydslesvig gennem Tiderne, red. af $M$. Kamphovener, I, Kbh. 1946, s, 43-108) s. 82 f.

53. E. Wadstein: Norden och Västeuropa i gammal tid (Sthlm. 1925) s. 53-74, citatet s. 70.

54. Smst. s. 66. Kilden er Chronicon Thietmari Merseburgensis III, 6, ed. R. Holtzmann (1935) s. 102 f.: >Ibi etiam (ved Slesvig) hostes suos (kejserens) foveam, quae ad defensionem patriae parata est, et portam, quae Wieglesdor vocatur, armis preoccupare videns ... omnes has munitiones viriliter exuperate. 
55. Dette må antages såvel iflg. Jankuhns som la Cours datering af Danevirke. H. Jankubn (note 61) s. 283 og 325 f. - Samme: Haithabu (4. Aufl. 1963) s. 78. - Vilh. la Cour: Danevirkestudier (1951) s. 54 og 184. - De seneste års gravninger har yderligere svækket Wadsteins formodning om, at den nævnte movea skulle være andet end hovedvolden.

56. Den danske Rimkronike I. Ghementrykket $1495 \mathrm{~m}$. variantapparat, udg. H. Toldberg (Kbh. 1961) s. 98.

57. A. Huitfeldt: Danmarckis Rigis Kronnicke (I), Kbh. 1603, s. 99 f.

58. Saxo (note 34) lib. 10, II, 3, s. 272. - A. S. Vedel: Den danske Krønicke (Kbh. 1575) s. CCXIII.

59. U. Petersen, se ovenfor. - Aa. Lauritsen, se nedenfor.

60. Foliomappe Danewerk, $1916 / 25 \mathrm{~m}$. breve fra Wadstein til Knorr af 8/9, 2/10, $3 / 121921$ og 12/2 1922. - Smlg. Knorrs korrespondance med landråden om nivellementer, $13 / 121921$ og 11/3 1922.

61. Citater fra Knorrs udgravningsberetning, H. Jankubn: Die Wehranlagen der Wikingerzeit $z$ wischen Schlei und Treene (Neumünster 1937), snit 1-5, s. 98-100.

62. F. Frahm: Der Transitverkehr Schleswig-Hollingstedt (Zeitschr, d. Ges. f. Schlesw.-Holst. Gesch., 60, 1930, s. 1-23).

63. Smst. s. 21.

64. H. Jankuhn (note 61) s. 174-77. - Samme: Haithabu (4. Aufl. Neumünster 1963) s. 148-51.

65. H. Jankubn (note 61) s. 121-23.

66. Smst., snit 9-10, s. $103 \mathrm{ff}$.

67. F. Frabm: Hygelstedt-Hollingstedt (Offa, 6/7, 1941/42, s. 108-17). Smlg. her s. 110 f. og Samme: Beiträge zur Baugeschichte des Danewerks (Nordelbingen, 10,1934 , s. $371-97)$.

68. H. Jankubn (note 61) s. 94. - Samme: Haithabu (1937) s. 41 ; (1956) s. 61 f.; (1963) s. $69 \mathrm{f}$.

69. Samme (note 61) s. 82. - Samme: Haithabu (1937) s. 112; (1956) s. 204; (1963) s. $238 \mathrm{f}$.

70. Aa. Lauritsen: Volden og den glemte vej. Et bidrag til Danevirkes bygningshistorie (Sønderj. årb., 1971, s. 1-78).

71. Smst. s. 71 (kort) og s. 72 (tekst).

72. Smst. s. 9 (kort) og s. 7, 24 og 28 (tekst).

73. Se kort, angiveligt fra 1757, i Pontoppidans Danske Atlas VII (Kbh. 1781) ved s. 30. Flere steder står der *Vold, som ei er meere til*, „Vold, som Danckwerth taler om*, o.s.v. Skent man ikke havde konstateret disse volde, turde man ikke bestride, at de havde eksisteret på Mejers tid. Men mig bekendt har landskabet ikke ændret sig særligt mellem 1640'erne og 1750'erne; hele perioden falder før udskiftningen.

74. Johs. Mejers kort i C. Danckwerth: Newe Landesbeschreibung der zwey Herzogthümer Schleswich und Holstein (Husum 1652) tab. XIIX og XIX sammenlignet med XX og XXII.

75. Vilh. la Cour, Sønderj. Månedsskr., 47, 1971, s. 152 og 188 f i tilknytning til Aa. Lauritsen (smst. s. 151 og 188) og til samme: Hedeby, Haddeby, Slesvig og Sli (smst., 43, 1967, s. 363-84 og s. 401-20).

76. Aa. Lauritsen (note 70 ) s. $16 \mathrm{f}$.

77. Smst. s. 31 .

78. Smst. s. 71 . 
79. Smst. s. 52 ff. $-H$. Jankubn (note 61) s. 182-87.

80. H. Jankubn: Ergebnisse und Probleme der Haithabugrabungen 1930-1939 (Zeitschr. d. Ges. f. Schlesw.-Holst. Gesch., 73, 1949) særlig s. 45 f.

81. Aa. Lauritsen (note 70) s. 8-12.

82. Smst. s. $45 \mathrm{ff}$.

83. Smst. s. 20 ff. og 30 f. - B. Svensson: En kanalteori (Sønderj. Månedsskr., 47, 1971, s. 310-14) særlig s. 314.

84. Aa. Lauritsen, svar til B. Svensson (Sønderj. Månedsskr., 47, 1971, s. 315-18) særlig s. 317.

85. Aa. Lauritsen (note 70) s. 19 og 43.

86. H. Schledermann: Danevirke-undersogelser ved Bustrup 1962-63 (Offa, 21/22, $1964 / 65$, s. 80-126) særlig s. 93-102 og s. 107. - Samme (note 40) s. 40-45. 